OPEN ACCESS

Edited by: Clara Armaroli,

University of Ferrara, Italy

Reviewed by:

Eduardo Siegle,

University of São Paulo, Brazi

Giovanni Coco,

The University of Auckland

New Zealand

${ }^{*}$ Correspondence: James B. Shope

jshope@ucsc.edu

Specialty section:

This article was submitted to Coastal Ocean Processes, a section of the journal

Frontiers in Marine Science

Received: 30 December 2018

Accepted: 24 April 2019

Published: 14 May 2019

Citation:

Shope JB and Storlazzi CD (2019)

Assessing Morphologic Controls on

Atoll Island Alongshore Sediment

Transport Gradients Due to Future

Sea-Level Rise.

Front. Mar. Sci. 6:245.

doi: 10.3389/fmars.2019.00245

\section{Assessing Morphologic Controls on Atoll Island Alongshore Sediment Transport Gradients Due to Future Sea-Level Rise}

\author{
James B. Shope ${ }^{1 *}$ and Curt D. Storlazzi ${ }^{2}$ \\ ${ }^{1}$ Institute of Marine Sciences, University of California, Santa Cruz, Santa Cruz, CA, United States, ${ }^{2}$ Pacific Coastal \\ and Marine Science Center, US Geological Survey, Santa Cruz, CA, United States
}

Atoll islands' alongshore sediment transport gradients depend on how island and reef morphology affect incident wave energy. It is unclear, though, how potential atoll morphologic configurations influence shoreline erosion and/or accretion patterns, and how these relationships will respond to future sea-level rise (SLR). Schematic atoll models with varying morphologies were used to evaluate the relative control of individual morphological parameters on alongshore transport gradients. Incident wave transformations were simulated using a physics-based numerical model and alongshore erosion and accretion was calculated using empirical formulae. The magnitude of the transport gradients increased with SLR: initial erosion or accretion patterns intensified. Modeled morphologic parameters that significantly influenced alongshore transport were the atoll diameter, reef flat width, reef flat depth, and island width. Modeled atolls with comparably small diameters, narrow and deep reef flats with narrow islands displayed greater magnitudes of erosion and/or accretion, especially with SLR. Windward island shorelines are projected to accrete toward the island's longitudinal ends and lagoon due to SLR, whereas leeward islands erode along lagoon shorelines and extend toward the island ends. Oblique island, oriented parallel to the incident deepwater wave direction, shorelines are forecast to build out leeward along the reef rim and toward the lagoon while eroding along regions exposed to direct wave attack. These findings make it possible to evaluate the relative risk of alongshore erosion/accretion on atolls due to SLR in a rapid, first-order analysis.

Keywords: atoll, islands, waves, sea-level rise, reef, morphology, erosion, shoreline

\section{INTRODUCTION}

Atolls are shallow, ring-shaped, coral platforms upon which small, low-elevation carbonate islands are often perched. Communities living on atoll islands are vulnerable to large wave events and changing climates (Storlazzi et al., 2015). As global climate warms, sea levels are projected to potentially increase by more than $2.0 \mathrm{~m}$ by 2100 due to seawater thermal expansion and glacial/ice cap melt (Church et al., 2013; Kopp et al., 2014; Slangen et al., 2014); the rate of sea-level rise (SLR) is projected to exceed the rate of coral reef platform vertical accretion (Montaggioni, 2005), leaving the future stability of these low-lying islands and their associated infrastructure, agriculture, and 
habitats uncertain. Global SLR and reef degradation (bleaching, ocean acidification, etc.) will reduce the reef platform's ability to attenuate wave energy and protect shorelines from wave-driven erosion and flooding hazards (Sheppard et al., 2005; Storlazzi et al., 2011; Grady et al., 2013; Ferrario et al., 2014; Shope et al., 2017). Incident wave dynamics, atoll morphology, and sediment composition (size, induration, etc.) influence shoreline erosional and accretional patterns; therefore, changes in atoll island alongshore erosion and/or accretion with SLR are location dependent and findings for one island may not necessarily apply to another.

Many studies have explored atoll island response to SLR (Roy and Connell, 1991; Woodroffe, 2008; Webb and Kench, 2010; Rankey, 2011; Ford, 2012; Yates et al., 2013; Purkis et al., 2016) and extreme wave events (Hoeke et al., 2013; Smithers and Hoeke, 2014), as well as reef controls on shoreline sediment mobilization and erosion (Sheppard et al., 2005; Storlazzi et al., 2011; Grady et al., 2013). Although these approaches elucidate large-scale trends, most of the analyses involve a few atoll islands (excepting Webb and Kench, 2010; Rankey, 2011), and/or have only considered the effects of recent SLR. Studies of island response to recent SLR may not accurately portray how islands will respond in the future when sea levels are predicted rise more rapidly and attain, if not exceed (Church et al., 2013; Kopp et al., 2014; Slangen et al., 2014) elevations when these islands formed during the mid-Holocene highstand (Dickinson, 2009; Kench et al., 2009). An atoll island's wave-driven, alongshore erosion and/or accretion patterns can differ from another's due to a number of factors, including variable morphology such as varying reef flat width, reef depth, and island shape. There has been limited exploration modeling of the erosional and accretional effect of changing wave conditions along atoll islands (Shope et al., 2017), however, it is currently unclear how alongshore erosion and/or accretion along different atoll islands' shorelines will respond to future SLR. Shope et al. (2017) and other studies have provided rationale as to how observed or projected erosion patterns may be influenced by atoll morphology, but there has not been a rigorous evaluation of how much influence morphologic variability affects alongshore processes on atolls.

To address morphologic controls on wave-driven erosion and accretion, Grady et al. (2013) and Quataert et al. (2015) modeled the effects of varying reef dimensions on wave parameters along reef-protected shorelines using a schematic or generalized bathymetry. Both of those studies, however, utilized one-dimensional (cross-shore) transect models. To capture alongshore variability, this approach requires multiple crossshore transects. Alongshore variability is more easily captured in a two-dimensional (2D) model, however, there has been limited two-dimensionally modeled analysis of wave-driven sediment transport along atoll island shorelines (Shope et al., 2017). Furthermore, these studies have remained site-specific, making it difficult to extrapolate finding to atoll islands as a whole and how differing atoll and island morphologies may affect the alongshore sediment transport process.

This study starts to fill this gap in understanding by proving an exploratory framework to assess the effect of differing morphologies and SLR on alongshore sediment transport gradients of atoll islands using 2D wave modeling which may be extrapolated to most atoll islands, expanding upon the methods of Shope et al. (2017). A physics-based 2D numerical wave model with varying schematized atoll bathymetries and island topographies with empirical sediment transport formulae were used to explore potential morphologic controls on wave-driven atoll island shoreline change patterns with SLR. A schematic model offers the benefit of allowing morphological parameters to be isolated and systematically varied to discern their relative controls on atoll island shoreline stability. A single morphological parameter (e.g., reef flat depth) can be altered while keeping the remainder of the morphology of the atoll constant, a condition that cannot be replicated from observational data of real atolls. Additionally, this approach allows for a large number of potential morphologies to be investigated in regards to their influence on shoreline change along an individual island. A brief overview of atoll and island morphology, characteristic ranges of morphologic parameters, and information about oceanographic forcing and wave transformation over atoll reefs is presented. The model setup and run conditions are then discussed, including formulation and descriptions of implementation, and then alongshore change calculations and data analyses. Finally, the results of changes in shoreline erosion with varying morphology and SLR are presented, followed by a discussion of these trends in relation to previous studies.

\section{ATOLL MORPHOLOGY AND INTERACTION WITH WAVES}

Atolls are shallow carbonate platforms that exhibit a wide range of morphologies created by successive vertical accretion of coral reefs as relative sea level increases with a central lagoon (Dickinson, 2004). The platform steeply rises from depths of a few kilometers to a shallow (often $<3 \mathrm{~m}$ water depth) annular reef flat. Atoll reefs have steep fore-reef slopes (Figure 1 and Table 1; Quataert et al., 2015), whereas the slope from the reef flat into the lagoon is usually relatively gentle $(\leq 1 / 20)$. Atoll diameters can vary widely (Table 1). Atolls are subject to a variety of wave conditions, ranging from small locally-generated wind waves to large swell waves generated far afield by storms and trade winds (Hoeke et al., 2013; Shope et al., 2016). Historical simulations indicate that the mean of the largest $5 \%$ of deepwater waves at many tropical Pacific atolls ranges from 4 to $8 \mathrm{~m}$ during the Northern Hemisphere winter and 2-4 m during its summer (Shope et al., 2016).

These waves and resulting wave-driven currents rework reefderived sediment into islands that sit atop the reef flat (Ohde et al., 2002). These islands are small, often with widths less than $1 \mathrm{~km}$ (Table 1), low in elevation, on average 2-3 $\mathrm{m}$ above sea level (Woodroffe, 2008), and have fronting reef flats of various widths (Table 1). Island lengths vary greatly, from $100 \mathrm{~s}$ of $\mathrm{m}$ to several $\mathrm{km}$.

The shallow reef crest dissipates most incident wave energy through depth-limited breaking (Ferrario et al., 2014). Wave energy that bypasses the reef crest is further dissipated by 


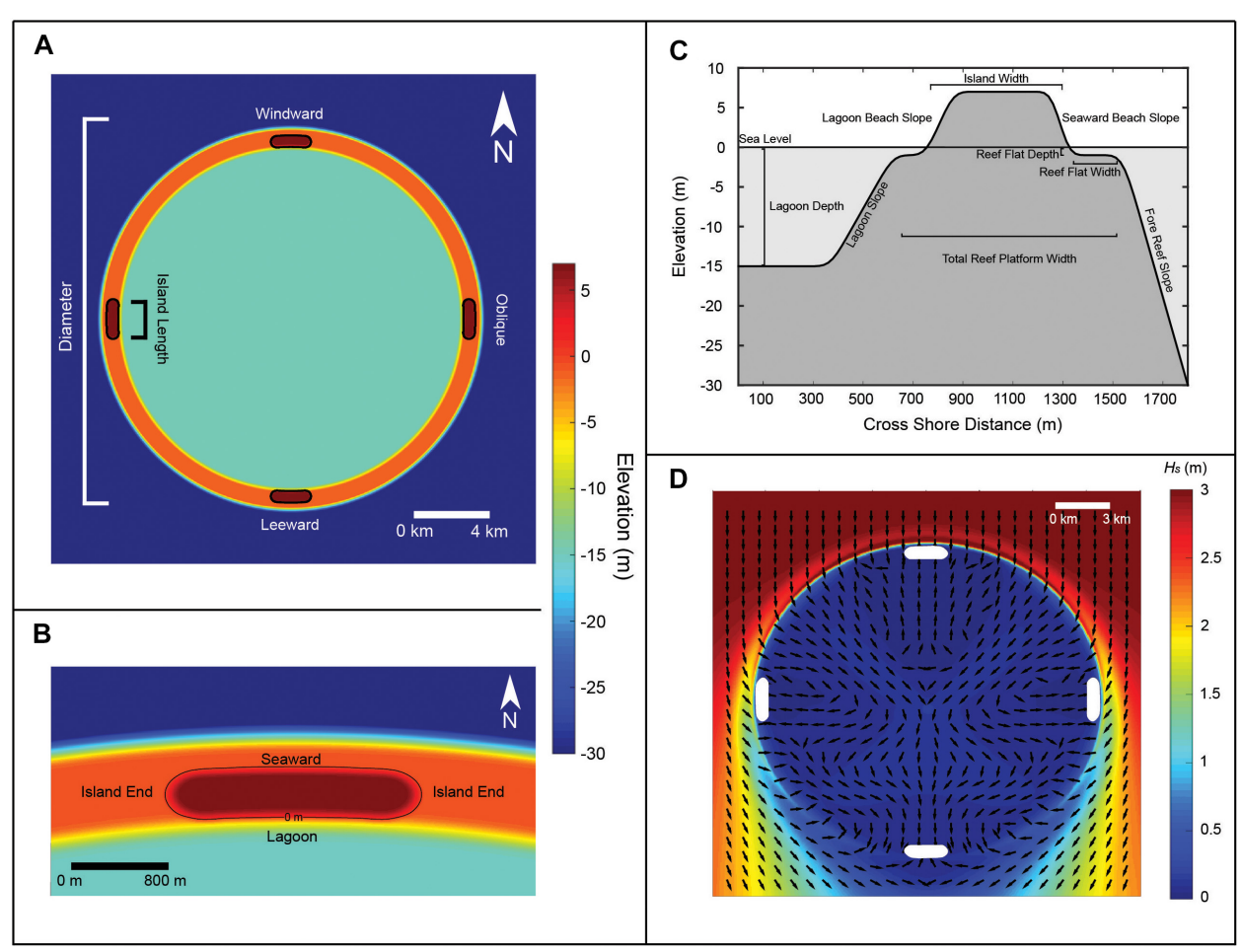

FIGURE 1 | Schematic model topography and bathymetry at the initial model configuration with example wave model output. (A) Topography and bathymetry at the atoll scale with labeled morphological parameters and island location in reference to incident waves coming from the top of the diagram. (B) A zoomed in image of the northern island indicating the shoreline divisions. Black lines indicate the $0 \mathrm{~m}$ contour. (C) Cross-section of schematized atoll island with labeled morphologic parameters. (D) Example wave height output for a $20 \mathrm{~km}$ atoll. White areas represent islands; black arrows represent wave direction. Waves approach from the top boundary of the model domain and refract around the atoll.

TABLE 1 | Morphological parameters varied within this study with a characteristic range of values determined from literature references, bathymetric data, and ESRI satellite imagery, along with values for the initial bathymetry configuration.

\begin{tabular}{|c|c|c|c|}
\hline Parameter & Range used & Initial & References \\
\hline Island width & $200-1000 \mathrm{~m}$ & $500 \mathrm{~m}$ & Woodroffe, 2008; Webb and Kench, 2010* \\
\hline Island length & $1000-5000 \mathrm{~m}$ & $2000 \mathrm{~m}$ & Webb and Kench, 2010* \\
\hline Ocean-facing slope & $1 / 3-1 / 12$ & $1 / 6$ & Grothe et al., 2010a,b; Rankey, 2011; Quataert et al., 2015; Beetham et al., 2016 \\
\hline Lagoon-facing slope & $1 / 12-1 / 20$ & $1 / 15$ & Grothe et al., 2010a,b \\
\hline Fore reef slope & $1 / 5-1 / 20$ & $1 / 10$ & Hoeke et al., 2011; Quataert et al., 2015; Beetham et al., 2016 \\
\hline Reef flat width & $50-950 \mathrm{~m}$ & $250 \mathrm{~m}$ & Woodroffe, 2008; Kench et al., 2009; Quataert et al., 2015* \\
\hline Reef flat depth & $25-200 \mathrm{~cm}$ & $1.0 \mathrm{~m}$ & Woodroffe, 2008; Yates et al., 2013; Quataert et al., 2015 \\
\hline Atoll diameter & $5-80 \mathrm{~km}$ & 20 km & Ford et al., 2013; Yates et al., 2013* \\
\hline Sea-level rise & $0-2.0 \mathrm{~m}$ & $0 \mathrm{~m}$ & Church et al., 2013; Kopp et al., 2014; Slangen et al., 2014 \\
\hline
\end{tabular}

Presented references were not the only literary basis to determine the ranges, but provide examples of morphologies within the modeled ranges. $*$ Denotes that ranges are supplemented by measurements using ESRI Satellite Imagery.

frictional interactions with the rough reef flat (Lowe et al., 2005; Quataert et al., 2015), with wider reef flats providing greater energy dissipation (Grady et al., 2013; Ferrario et al., 2014; Quataert et al., 2015). With SLR or reef degradation, reef flats become deeper, reducing wave interaction with the underlying reef and thus increasing wave energy delivered to shorelines (Gourlay, 1996; Pequignet et al., 2011; Taebi and Pattiaratchi, 2014; Hoeke et al., 2015), and deeper reef flats are associated with greater alongshore sediment transport (Storlazzi et al., 2011; Grady et al., 2013).
Atoll islands are dynamic features whose shorelines respond to changing wave conditions on seasonal (Kench and Brander, 2006) and decadal (Rankey, 2011) timescales. As a result, with past SLR, atoll islands have had complex responses: many have been found to reorganize on the reef flat and even increase in total area (Webb and Kench, 2010; Yates et al., 2013). However, these trends may not persist when sea level approaches or exceeds the mid-Holocene highstand levels under which the islands formed, or as SLR rates accelerate beyond recently observed rates (Dickinson, 2009). 


\section{MATERIALS AND METHODS}

\section{Model Schematization and Bathymetry}

The dimensions of many atolls and atoll islands from peerreviewed studies and satellite imagery were analyzed to determine characteristic ranges of dimensions to inform a schematized bathymetry/topography (Table 1). Using this compilation, idealized atolls were created using characteristic values within the described range for each dimension.

This schematized bathymetry/topography was a circular atoll ring with four islands situated at $0,90,180$, and $270^{\circ}$ from north along the rim to investigate the relative influence of island position on the atoll (Figure 1A). The lagoon depth was $15 \mathrm{~m}$, as it is assumed that there is negligible interaction between the low amplitude, high-frequency waves in the lagoon and the lagoon bottom. Beaches were created by scaling the edges of the islands using the beach slopes listed in Table 1. The beach slopes at the island ends were assumed to change linearly between the ocean-facing and lagoon beach slopes. Islands were elongate with rounded ends and positioned a consistent distance from the reef rim and the lagoon rim (Figure 1B). An "initial" atoll configuration was selected based on the ranges summarized in Table 1. This initial schematization was a base from which individual morphological parameters were varied within a given range, while keeping the others constant.

\section{Model and Setup}

Incident wave simulations were modeled the spectral Simulating Waves Nearshore (SWAN) model (Booij et al., 1999; Ris et al., 1999), which solves the spectral action balance equation for boundary conditions, within the DELFT3D-WAVE module. Each simulation computed wave transformations for one set of boundary conditions, with no temporal evolution of the model boundary forcings. Most default model settings were used, but the bottom friction of the reef was formulated using a Madsen coefficient of $0.1 \mathrm{~m}$ following Hoeke (2010) and wind-wave growth was not enabled. The wave direction bins were set to be 95 resolve the wave transformations and diffractions across the reef. To adapt SWAN for the rapid and dramatic changes in slope and depth that are found in an atoll environment, each bathymetry was smoothed to the same extent by an iterative Gaussian filter. This methodology is intended to determine the relativistic effects of individual parameters (e.g., a wider versus a narrower reef flat) between model runs. These smoothed bathymetries retained the same structure and scale of the pre-smoothed schematic, not significantly impacting the final results.

For atoll diameters of 5-20 km, the model was composed of two grids, a $60 \mathrm{~m}$ coarse resolution grid representing the entire atoll and a $20 \mathrm{~m}$ fine-resolution grid focused on the northern island of the atoll. A $20 \mathrm{~m}$ resolution grid was the finest grid that could be modeled coupled with 95 directional bins. Higher resolutions would result in SWAN out of memory computation errors. This resolution is comparable to available bathymetry/topography data for remote atolls (e.g., Shope et al., 2017). For larger atolls, these grids were further nested in a $180 \mathrm{~m}$ grid for $40 \mathrm{~km}$ diameter, and in a $320 \mathrm{~m}$ grid for 60 and $80 \mathrm{~km}$ diameters. The boundary deep-water wave conditions of the model were a significant wave height $\left(H_{\mathrm{s}}\right)$ of $3 \mathrm{~m}$ with a peak wave period $\left(T_{\mathrm{p}}\right)$ of $15 \mathrm{~s}$, and a wave direction $\left(\theta_{\mathrm{W}}\right)$ of $0^{\circ}$ from north to represent large swell conditions (Figure 1D). Boundary conditions did not change, thus only one calculation of nearshore wave transformation was needed per morphological configuration. Simulating one wave condition allowed for a clearer analysis of differing atoll morphologies. Also, SWAN does not simulate the infragravity waves needed to fully explore how changing wave periods may affect alongshore sediment transport gradients. Sea level within the model was considered to be mean sea level relative to the atoll island shorelines. Reef and beach slope variations were too small to be well represented at the model resolutions; therefore, analysis of the alongshore transport gradient influence of these slopes was outside the capability of this study. Finally, SLR was modeled as a suite of static water elevations from $+0.0 \mathrm{~m}$ to $+2.0 \mathrm{~m}$ at $0.5 \mathrm{~m}$ increments to represent potential water level conditions by 2100 (Church et al., 2013; Kopp et al., 2014; Slangen et al., 2014). As SWAN was not coupled to a hydrodynamic flow or numerical morphology component, SLR was not represented as a continuous change to mimic the morphological evolution over the next century. Instead, each simulation represents how that exact morphology would react to higher water level conditions. Similarly, the alongshore flow generated by wave setup (and its sediment transport) was not simulated within this study as coupling to a flow model would be necessary to fully resolve the alongshore water level gradient due to wave radiation stresses. An empirical methodology to determine water level-driven alongshore transport was explored, but the transport values were found to be negligible compared to the wave-driven magnitudes. Wave simulations were modeled for each combination of morphologic variation and sea level. Short term water level fluctuations due to tidal forcing were not modeled, but their instantaneous influence can be inferred by referring to the smaller increments of SLR that were modeled. The depth of the reef flat was assumed to be static with respect to SLR. The reef flat is the primary filter for incident wave energy that drives sediment transport (Ferrario et al., 2014), and the vertical accretion of an atoll reef flat in a high energy area is $1-4 \mathrm{~mm} / \mathrm{y}$ (Montaggioni, 2005) which is much smaller than projected SLR rates over the next century (Church et al., 2013; Kopp et al., 2014; Slangen et al., 2014). For this reason, reef flat growth was assumed to be negligible compared to sea level changes.

\section{Alongshore Sediment Transport and Shoreline Change Modeling}

The instantaneous alongshore sediment flux was calculated via the empirical Coastal Research Engineering Center (CERC) equation as formulated by Komar (1971) and Rosati et al. (2002), which has been used in previous shoreline change studies (e.g., Ashton and Murray, 2006; Adams et al., 2011). The formula was adapted for use along atoll island shorelines using the 
methodology described by Shope et al. (2017). The CERC formula is given as:

$$
\begin{gathered}
Q_{l}=\frac{I_{l}}{\left(p_{s}-p_{w}\right) g N_{o}} \\
I_{l}=K \frac{1}{8} p_{w} g H_{b}^{2} C n \sin (\alpha) \cos (\alpha) \\
C=\frac{g T}{2 \pi} \tanh \left(\frac{2 \pi h}{L_{o}}\right)
\end{gathered}
$$

where $Q_{l}$ is the alongshore sediment transport rate $\left(\mathrm{m}^{3} / \mathrm{s}\right), p_{s}$ is the density of carbonate sand (the bulk density of coral, $1400 \mathrm{~kg} / \mathrm{m}^{3}$, was used; Grigg, 1982; Harney and Fletcher, 2003), $p_{w}$ is the density of seawater $\left(1024 \mathrm{~kg} / \mathrm{m}^{3}\right), N_{o}$ is the volumetric concentration of solid grains $(\sim 0.6), I_{l}$ is the immersed weight transport rate, $H_{b}$ is the breaking wave height, $C$ is nearshore wave celerity (m/s, a function of $H_{s}, T_{p}$, and $h$; e.g., Komar, 1998), $n$ is the shallow water assumption for wave group velocity $(0.5), \alpha$ is the angle of incidence between $\theta_{\mathrm{w}}$ and shoreline direction, $h$ is water depth (m), $g$ is the acceleration due to gravity $\left(\sim 9.81 \mathrm{~m} / \mathrm{s}^{2}\right)$, and $L_{o}$ is wave length (m, a function of $T_{p}$ and $h$ (e.g., Komar, $1998)$. The tuning parameter $(K)$ in Equation (1b) was varied at each model cell following Smith et al. (2009) to generate a better approximation of transport magnitudes. $K$ was calculated as:

$$
K=0.7 \xi_{b}=0.7 \frac{m}{\sqrt{\frac{H_{b}}{L_{o}}}}
$$

where $m$ is the beach slope. CERC calculates alongshore transport potential based on wave energy gradients assuming homogenous sized material.

Traditionally, when utilizing the CERC equation, $H_{b}$ and $\theta_{\mathrm{w}}$ are computed at a water depth of approximately $5 \mathrm{~m}$ (Adams et al., 2011). Along atoll reefs, there are two breaker zones: the first at the reef crest and the second at the island shoreline. The rapidly shoaling bathymetry causes the incident wave energy to decay such that breaking conditions at the reef crest do not represent the nearshore conditions driving alongshore transport. Therefore, $H_{s}$ and $\theta_{\mathrm{w}}$ output by SWAN along the shoreline were used in CERC calculations (Shope et al., 2017), as these conditions dominate the island's alongshore wave energy gradient.

The CERC formula was developed for long, linear, siliciclastic coastlines (e.g., Adams et al., 2011). Along more non-linear atoll island morphologies, it was necessary to remove highly local patterns to discern shoreline-scale (Figure 1B) trends. SWAN outputs in the very nearshore demonstrated a great deal of alongshore variability between neighboring points due to the nearshore model resolution $(20 \mathrm{~m})$ and the rectilinear grid. At this resolution, wave energy varies slightly and non-linearly from point to point alongshore, resulting in highly variable transport rates. Wave inputs and transport magnitudes were smoothed using a low-pass filter to remove rectilinear modelgenerated local variations smaller than approximately $1 \mathrm{~km}$ (20\% of the initial island alongshore circumference) along the curvilinear island shorelines. This threshold was determined to give the general alongshore drift patterns of the island as a whole, while removing most sub-shoreline scale variation. As the purpose of this study was to determine shoreline-scale changes in transport gradients under idealized morphologies and conditions, smoothing these alongshore values created a clearer picture of general shoreline-scale alongshore transport.

\section{Limitations and Assumptions}

It is important to note that the CERC formula only calculates sediment transport in the alongshore direction, discounting the effects of transport onto the island and into the lagoon (Woodroffe et al., 1999; Kench et al., 2008; Smithers and Hoeke, 2014; McLean and Kench, 2015). Recent studies have investigated cross-shore sediment transport (Hoeke et al., 2013; Smithers and Hoeke, 2014; Cheriton et al., 2016), but do not compare cross-shore and alongshore transport processes. Also, these studies highlight very large events, and the average sediment transport they discuss is skewed toward these large events. Finally, there are no atoll island-wide measurements of alongshore sediment flux with which to compare in the literature. Kench and Brander (2006) concluded that due to the circular nature of sediment transport around reef islands at shorter time scales, alongshore transport processes control island morphological change with little influence from cross-shore processes. As the wave simulations and transport calculations were instantaneous and this research is specifically focused on alongshore processes, no cross-shore processes were simulated. However, processes such as infragravity wave overwash will increase with SLR (e.g., Quataert et al., 2015; Cheriton et al., 2016), and must be considered to fully project atoll island morphological evolution. It was assumed that island shorelines were composed of unlimited, unconsolidated sandsized material despite atoll shorelines often including beach rock and shingle that inhibit wave-driven sediment transport (Vousdoukas et al., 2009). Additionally, the calculated slope utilized in Equation (2) were muted as the resolution of the model $(20 \mathrm{~m})$ resulted in smaller slope calculations, a smaller $K$ tuning parameter, and smaller transport magnitues. However, the calculated transport magnitudes were only used to derive the relative effects of different atoll and island morphologies on transport gradients and were not analyzed as exact replications of real-world processes, of which there is little-to-no observational data available with which to compare. This simplified approach reduces location dependence of the analysis due to heterogeneity in island sedimentologies (e.g., Kench et al., 2005; Rankey, 2011). Additionally, these instantaneous calculations of transport gradients were rapid, allowing a larger number of morphological scenarios to be investigated (order of 1000s) compared to computationally expensive numerical morphodynamic models. Finally, the finest model grid resolution of $20 \mathrm{~m}$ was somewhat too coarse to represent exact alongshore transport magnitudes. The quantitative results are therefore discussed relativistically in the results section. Different morphology configurations produced relatively different transport magnitudes in response differing nearshore wave energy. These trends in transport magnitudes between modeled scenarios hold true despite the fact that the calculated magnitudes may be unrealistic. 


\section{Coastal Change Analysis}

For the purposes of analysis and comparison with observational studies, alongshore sediment transport gradients were represented as potential erosion and accretion values. Potential erosion and accretion were calculated as the divergence of the calculated alongshore transport: $\partial Q_{l} / \partial x$, where $x$ is the distance alongshore (e.g., Pelnard-Considere, 1956). Positive divergence values were defined as erosion and negative values as accretion. These magnitudes of shoreline change were then divided by the local grid resolution $(20 \mathrm{~m})$ to represent the erosion or accretion magnitude per $\mathrm{m}$ of shoreline. These processes are also influenced by local sediment size, which must be considered in any site-specific analysis. But in an idealized model, the size is not critical to elucidate transport trends due to varying morphologies and SLR. It is important to note that these gradients were calculated from the single swell wave condition and represent an instantaneous estimation of alongshore transport. As such, the morphology of the islands was not altered within the model in response to the calculated erosion and accretion values. Instead, each simulation should be viewed as how an atoll's configuration affects these instantaneous transport gradients. For analysis, each island was divided into four shorelines: one seaward, one lagoon, and two island ends (Figure 1B). Seaward shorelines face the ocean, lagoon shorelines face the central lagoon, and island end shorelines are the longitudinal ends of the islands. For oblique islands, a windward island end faces the direction of incident wave energy and a leeward island end faces away from the direction of incident wave energy. The erosion/accretion values along each shoreline were summed to discern net shoreline erosion/accretion for each scenario. These values were then compared relative to the net shoreline change for the same shoreline under different sea levels and/or morphologies. The absolute output magnitudes were not discussed within the coastal change analysis, as this idealized model aimed to explore the relative impact of different morphological parameters on shoreline erosion/accretion. This approach has been useful to explore regions where there are little-to-no calibration data for a shoreline change model (e.g., Shope et al., 2017). The purpose and strength of this numerical model to empirical erosion approach is not to simulate historic observations exactly, but rather gain confidence that physical processes are represented. This allows for determining the relative contribution of the variations in geometries (e.g., different widths, depths, and scales) to alongshore transport patterns.

\section{RESULTS}

The influence of varying island width, reef flat width, reef flat depth, and atoll diameter on erosion and/or accretion magnitudes are described here. Although explored, variations in island length are not presented, as erosion and accretion were found to be comparably insensitive to changes in this parameter via this methodology. For windward and leeward islands, results for both island ends were similar. Therefore, results of one representative island end shoreline are presented. For oblique islands, the seaward and leeward island end shorelines behaved differently, and results are presented for each shoreline. Throughout, the magnitude of the transport patterns increased with SLR; shorelines that were initially erosive or accretive with lower sea level generally displayed greater erosion or accretion magnitudes with SLR. The following describes the shoreline change trends by island, with each major shoreline of that island being described in each section. Data used in this study can be found and downloaded at: Shope and Storlazzi, 2019, http://doi.org/10. 5066/P9U28JFO.

\section{Windward Islands}

Seaward shorelines were projected to be erosive under all morphology ranges. Smaller island widths $(<1 \mathrm{~km}$, Figure 2A1), narrower reef flats $(<500 \mathrm{~m}$, Figure $2 \mathrm{~B} 1)$, deeper reef flats $(>1 \mathrm{~m}$, Figure $4 \mathrm{C1})$ and smaller atoll diameters $(<20 \mathrm{~km}$, Figure 2D1) resulted in greater erosion. Very narrow reef flats $(<150 \mathrm{~m})$ had intense erosion, even at low values of SLR. Medium-sized atolls $(20-40 \mathrm{~km})$ generally had lower erosion than larger and smaller diameters. The greatest magnitude of erosion with SLR occurred with deep $(>1.5 \mathrm{~m})$ and narrow reef flats. Lagoon shorelines were accretive under all morphologies. Smaller island widths (Figure 3A2), narrower reef flats (Figure 2B2), deeper reef flats (Figure 2C2), and smaller atoll diameters (Figure 2D2) resulted in enhanced accretion. Medium-sized atolls generally had smaller accretion magnitudes than other atoll diameters. The greatest magnitude of accretion with SLR occurred with deep reef flats and narrow island widths $(<300 \mathrm{~m})$. Island end shorelines were accretive under most morphology ranges, however, the magnitudes were the smallest for all islands and shorelines in this study (Figures 2A3-4D3). Narrow reef flats were associated with more accretion (Figure 2B3). Otherwise, the changes with morphologic parameters were small and did not follow a consistent pattern.

\section{Leeward Islands}

Seaward shorelines were projected to be slightly erosive at $0 \mathrm{~m}$ SLR and become more accretive with SLR. The magnitudes overall were generally small (Figures 3A1-3D1). Small island widths $(<1 \mathrm{~km})$, deeper reef flats $(>1 \mathrm{~m})$, and narrow reef flats $(<500 \mathrm{~m})$ were characterized by more accretion. The increase in accretion was greatest for small island widths. Lagoon shorelines were erosive under almost all morphologies. Smaller island widths (Figure 3A2), narrower reef flats (Figure 3B2), and deeper reef flats (Figure 3C2) were characterized by more erosion. The greatest magnitude of erosion occurred with deep reef flats and narrow island widths. At atoll diameters smaller than $10 \mathrm{~km}$ the lagoon shoreline was erosive (Figure 3D2). Island end shorelines were accretive under almost all morphologies. Smaller island widths (Figure 3A3), narrower reef flats (Figure 3B3), and deeper reef flats (Figure 3C3) had greater accretion magnitudes. The greatest accretion magnitudes occurred with deep reef flats and narrow island widths. At an atoll diameter of $5 \mathrm{~km}$ this shoreline was erosive, but at atoll diameters greater than $5 \mathrm{~km}$ it was accretive (Figure 3D3). 


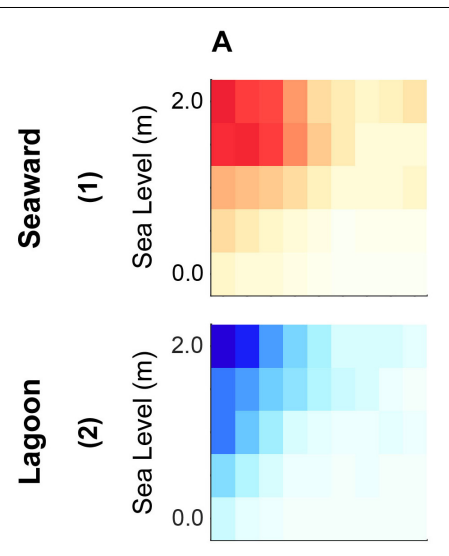

B
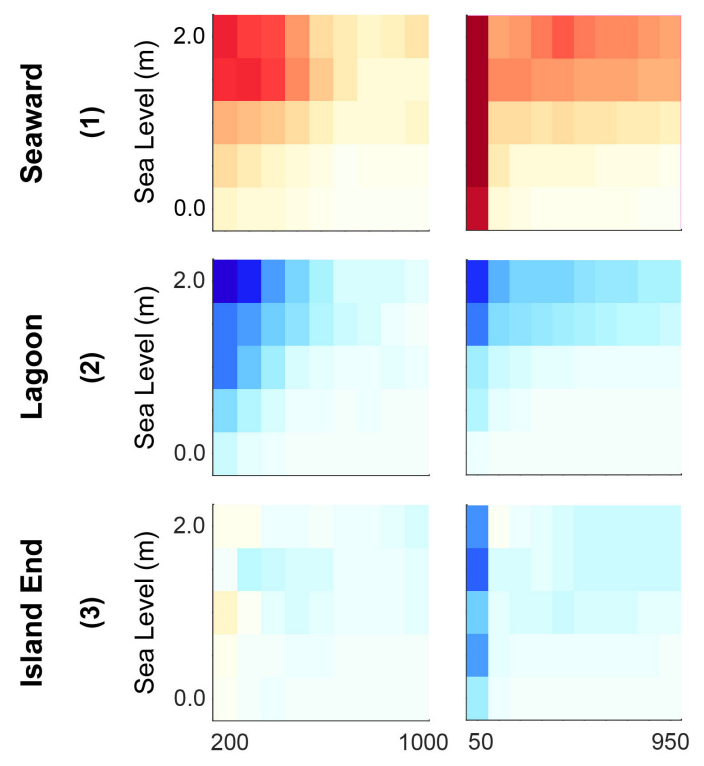

C
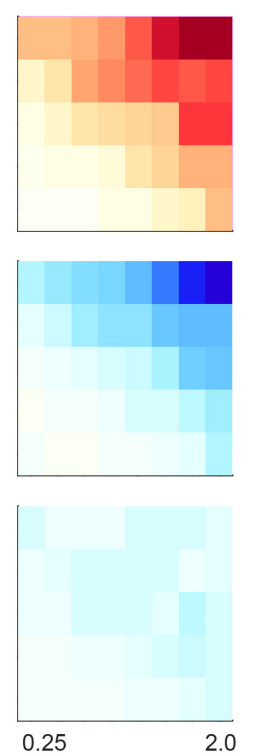

D
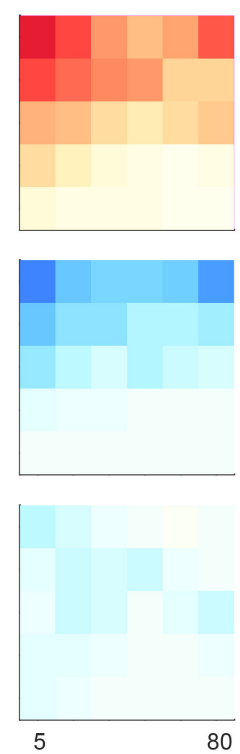

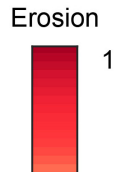

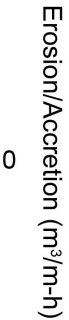

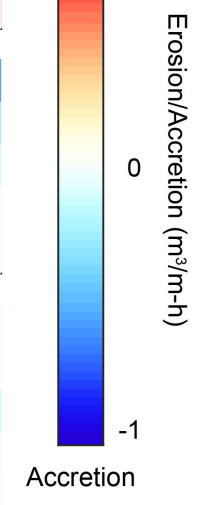

Island Width $(\mathrm{m}) \quad$ Reef Flat Width $(\mathrm{m})$ Reef Flat Depth $(\mathrm{m}) \quad$ Atoll Diameter $(\mathrm{km})$

FIGURE 2 | Relative changes in shoreline erosion/accretion magnitudes with morphological parameter ( $x$-axes) and SLR ( $y$-axes) for the windward island. Rows describe (1) seaward, (2) lagoon, and (3) island end shorelines; columns denote morphological parameters (A) island width, (B) reef flat width, (C) reef flat depth, and (D) atoll diameter. Red indicates net erosion and blue net accretion, with increasing color intensity indicating greater magnitude. The color ramp is linear, but absolute magnitudes are unlisted to address only relative changes.
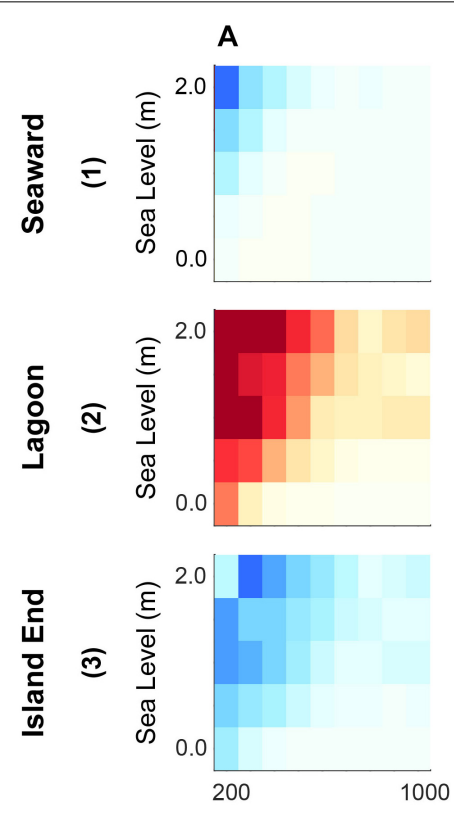

B
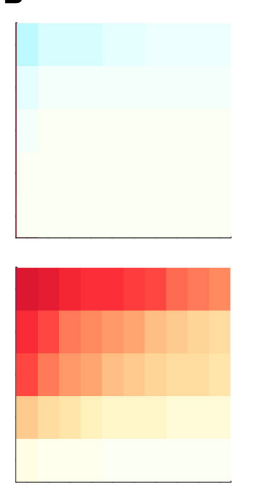

C
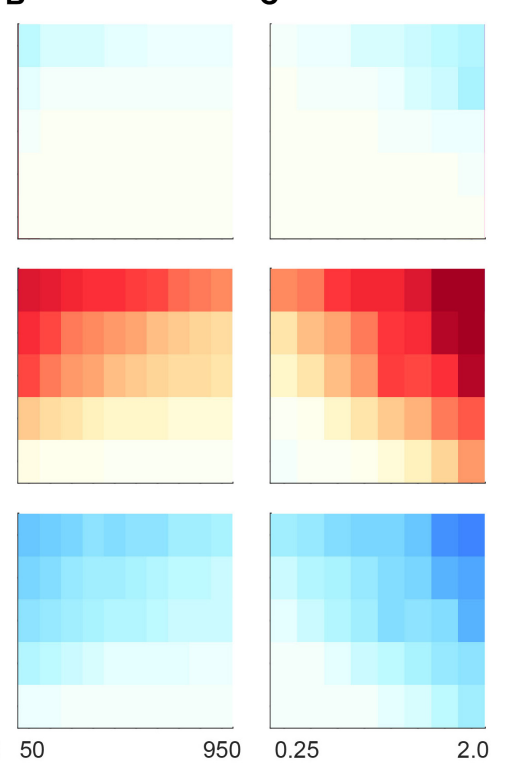

D
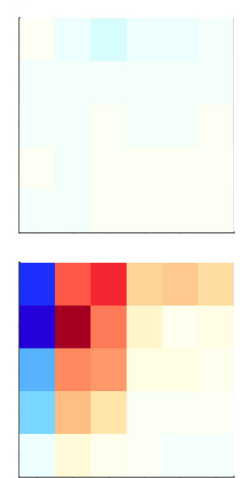

Erosion
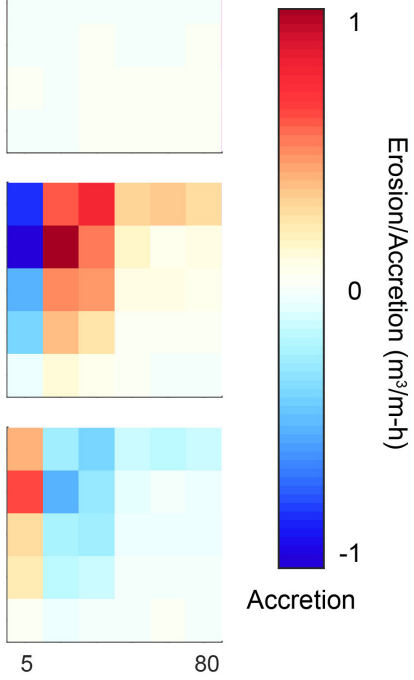

Island Width $(\mathrm{m})$

Reef Flat Width (m)

Reef Flat Depth (m)

Atoll Diameter $(\mathrm{km})$

FIGURE 3 | Relative changes in shoreline erosion/accretion magnitudes with morphological parameter ( $x$-axes) and SLR (y-axes) for the leeward island. Rows describe (1) seaward, (2) lagoon, and (3) island end shorelines; columns denote morphological parameters (A) island width, (B) reef flat width, (C) reef flat depth, and (D) atoll diameter. Red indicates net erosion and blue net accretion, with increasing color intensity indicating greater magnitude. The color ramp is linear, but absolute magnitudes are unlisted to address only relative changes. 


\section{Oblique Islands}

Seaward shorelines demonstrated similar trends to the windward islands' seaward shorelines, as all were projected to be erosive over the range of morphologic variations. Smaller island widths $(<1 \mathrm{~km}$, Figure 4A1), narrower reef flats $(<500 \mathrm{~m}$, Figure 4B1), deeper reef flats ( $>1 \mathrm{~m}$, Figure $4 \mathrm{C1}$ ), and smaller atoll diameters $(<20 \mathrm{~km}$, Figure 4D1) had more erosion. Medium-sized (20$40 \mathrm{~km}$ ) atolls generally displayed less erosion than other diameters. The greatest magnitude of erosion occurred with deep and narrow reef flats. The lagoon shoreline exhibited similar trends to the windward island lagoon shoreline, being accretive over the range of morphologic variations. Smaller island widths (Figure 4A2), narrower reef flats (Figure 4B2), deeper reef flats (Figure 4C2), and smaller atoll diameters (Figure 4D2) had greater accretion. Both small and large atoll diameters had greater accretion than middling sizes. The greatest magnitude of accretion occurred with narrow island widths. Leeward island end shorelines were accretive under all modeled morphologies. Larger island widths (Figure 4A3), narrower reef flats (Figure 4B3), deeper reef flats (Figure 4C3), and smaller atoll diameters (Figure 4D3) displayed increased accretion. The greatest magnitude of accretion occurred with deep reef flats. This was the only shoreline in the study where larger island widths were associated with a greater magnitude of shoreline change. Windward island end shorelines were erosive under all morphologies. Smaller island widths (Figure 4A4), narrower reef flats (Figure 4B4), deeper reef flats (Figure 4C4), and smaller atoll diameters (Figure 4D4) had increased erosion, with the greatest magnitude occurring with deep reef flats.

\section{DISCUSSION}

The results are discussed at two scales. The first focuses on how individual morphological parameters affect alongshore transport gradients from an atoll-scale to island-scale parameters (i.e., the island width). The second section considers these parameters together: including how they may influence the morphological evolution of individual islands and enable a relativistic classification of island shoreline stability with SLR.

\section{The Influence Morphological Parameters Atoll Diameter}

Atolls with smaller diameters $(5-10 \mathrm{~km})$ were projected to have greater shoreline erosion than comparably larger atolls. Wave refraction around the atoll and wave shadowing by the
A

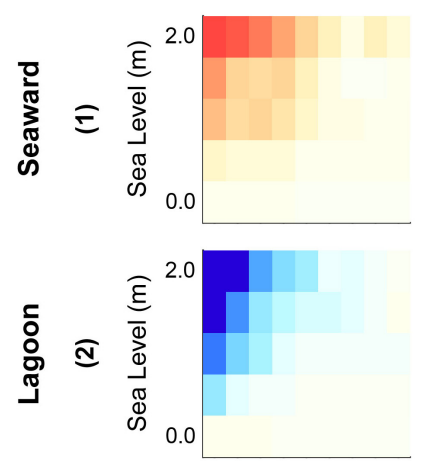

을

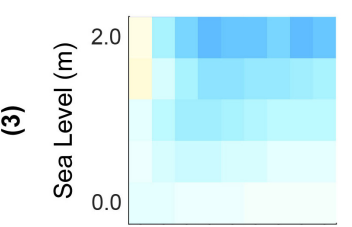

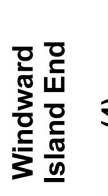

B
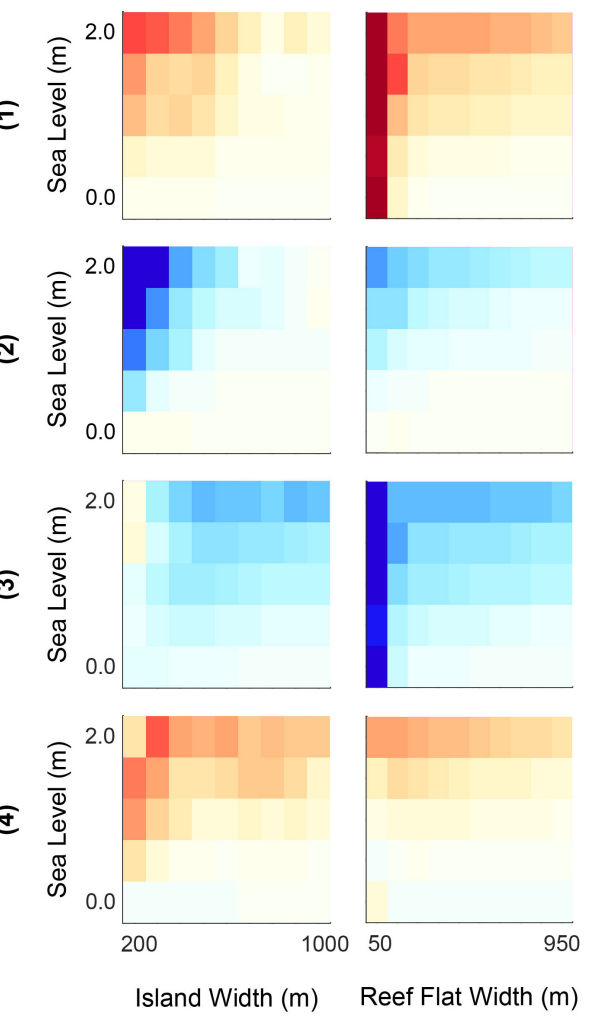

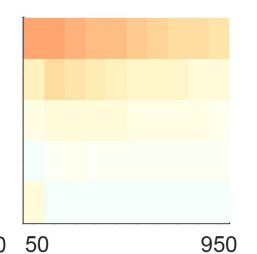

Reef Flat Width $(m)$
C
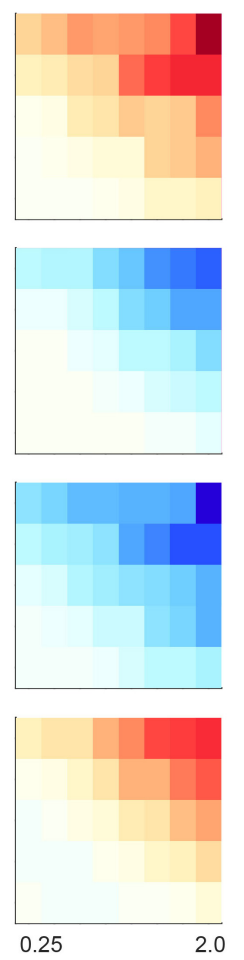

Reef Flat Depth $(\mathrm{m})$
D

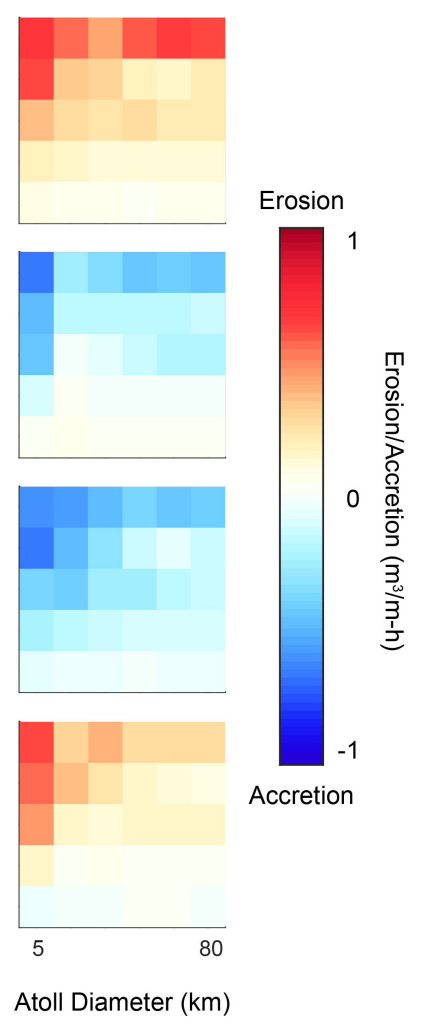

FIGURE 4 | Relative changes in shoreline erosion/accretion magnitudes with morphological parameter ( $x$-axes) and SLR (y-axes) for the oblique island. Rows describe (1) seaward, (2) lagoon, (3) leeward island end, and (4) windward island end shorelines; columns denote morphological parameters (A) island width, (B) reef flat width, (C) reef flat depth, and (D) atoll diameter. Red indicates net erosion and blue net accretion, with increasing color intensity indicating greater magnitude. The color ramp is linear, but absolute magnitudes are unlisted to address only relative changes. 
windward island (Figure 1D) likely account for these differences. Mandlier and Kench (2012) observed that changing the aspect ratio of an oblate coral reef platform affected wave refraction and convergence patterns; the patterns are likely similar for a circular platform with a central lagoon. On smaller atolls, the reef flat and islands have greater curvature, increasing refraction, directing wave energy toward the island shorelines that would normally be bypassed near the island ends. Additionally, a windward island that covers a greater fraction of atoll circumference, such as in the smallest diameter model, will cause a wave shadow that affects incident wave energy along the leeward island, changing transport gradient. For atoll diameters greater than or equal to $10 \mathrm{~km}$, the leeward island's transport gradients reverse, indicating that it is no longer in the northern island's shadow. At the largest atoll diameter range, wave refraction is less, striking seaward shorelines closer to perpendicular, and reduced reef frictional dissipation from traversing a shorter (non-refracted) distance across the reef flat. These results indicate that atoll size is a crucial model parameter, and transport patterns projected for a smaller atoll may not necessarily scale to a larger atoll.

\section{Reef Flat Width}

Narrower reef flats were projected to exhibit greater erosion with SLR. Narrower fringing reef flats lead to increased nearshore $H_{s}$ because less wave energy is attenuated through frictional dissipation (Lowe et al., 2005; Grady et al., 2013; Ferrario et al., 2014; Quataert et al., 2015), resulting in greater transport gradients between the seaward and lagoon shorelines. Very narrow reef flats $(<50 \mathrm{~m})$ along windward and oblique islands often generated comparably high magnitude erosion due to the coarseness of the model resolution and smoothing resulting in a poorer representation of the very narrow reef within the wave model. However, this result does follow reports of narrower reef flats allowing more energy to reach shore (e.g., Quataert et al., 2015), reducing wave refraction, and resulting in greater alongshore transport. For leeward islands, very narrow reef flats do not have a similar effect waves that reach leeward islands lose much of their energy as they traverse the northern reef platform width before crossing the lagoon or are refracted around the atoll to intersect the southern shoreline. However, the trend between wider reef flats and more reduced alongshore erosion was greatest on leeward islands. Waves that reach lagoon shorelines of leeward islands traverse the total reef platform and the lagoon before reaching shore. When crossing the reef flat, these waves refract, traveling a greater distance than the platform width. As a result, changes in reef flat width are magnified in these conditions.

\section{Reef Flat Depth}

Increasing reef flat depth reduces depth-limited breaking at the reef crest, and frictional energy dissipation, thus increasing sediment transport potential. Conversely, shallower reef flats afford more protection from wave attack and reduce erosion. Previous studies have observed increased shoreline erosion with increasing reef depths in the Seychelles due to reef degradation (Sheppard et al., 2005) and in models of fringing reef sediment dynamics in Hawaii (Storlazzi et al., 2011; Grady et al., 2013).

\section{Island Width}

Narrower islands lead to greater nearshore $H_{s}$ and increased transport in all scenarios. Alongshore sediment erosion and deposition around an atoll island is dominated by the alongshore wave energy gradient with sediment migrating from regions of high energy to low (Kench and Brander, 2006; Kench et al., 2006, 2009; Beetham and Kench, 2014; Smithers and Hoeke, 2014). A wider island decreases the energy (and sediment transport) gradient from the seaward to lagoon shorelines, because the approximately same change in alongshore energy is divided over a longer alongshore distance. A secondary impact is that for a given reef flat width, wider islands result in a wider reef platform. The reef flat width was held constant at $250 \mathrm{~m}$ within the model, so the reef platform width varied along with island width which resulted in increased energy dissipation and less sediment transport (Grady et al., 2013). Island width had a stronger impact on erosion magnitudes than reef flat widths except for narrow $(<150 \mathrm{~m})$ reef flat widths; this implies that under the range of conditions studied here, alongshore distance affects the energy gradient more than incident wave energy dissipation provided by the reef under the control scenario.

\section{Implications for Atoll Island Stability}

With SLR, all shorelines exhibited an intensification of a preexisting alongshore erosion/accretion patterns. Mandlier and Kench (2012) found that with increased water depths, the wave convergence zones that help form reef islands migrate from the windward side of a reef platform to the leeward side, increasing erosion along the windward shoreline of an island. This process manifests within the modeled results as an intensification of erosion along the windward and oblique islands' seaward shorelines and the leeward island's lagoon shoreline. Following the migration of the wave convergence zone, model results indicate that windward islands would erode along the seaward shoreline (Figure 5), with its sediment being transported to the island ends and the lagoon shorelines in accordance with observational studies (e.g., Webb and Kench, 2010), which would widen these beaches. However, other studies have found conflicting results. Yates et al. (2013) observed windward islands accreting along their seaward shorelines on Manihi Atoll; Woodroffe (2008) describes seaward shorelines as long-term sediment sinks and erosion along these shorelines as ephemeral. Additionally, Shope et al. (2017) found that with SLR, modeled windward islands eroded along seaward shoreline and lagoon shorelines, accreting at the islands' ends and parts of the shoreline with a wider reef flat. Similarly, the oblique islands would extend leeward along the reef rim as the leeward beaches build out and toward the lagoon (Figure 5) as the transport gradient between the seaward and lagoon shorelines is intensified. Leeward island transport patterns were more complex. Leeward islands receive wave energy from waves that refract around the atoll and smaller waves that are able to bypass the reef rim, which mobilize sediment along the seaward and lagoon shorelines, respectively (Figure 1D). However, there is generally an asymmetry in this energy resulting in net accretion along the island ends and seaward shorelines as observed at Funafuti 
(Webb and Kench, 2010) and Manuae (Yates et al., 2013) Atolls and modeled at Wake and Midway Atolls (Shope et al., 2017). As sea level increases, so does the energy gradient asymmetry following the leeward migration of the wave convergence zone (Mandlier and Kench, 2012), increasing accretion along the island ends and seaward shoreline. As a result, with SLR, leeward islands would become longer, as sediment is redistributed to the ends, and narrower as transport gradients on the lagoon and seaward shorelines to the island ends intensify (Figure 5). Many atoll islands have remained morphologically stable during recent observational periods (e.g., Webb and Kench, 2010; Purkis et al., 2016), though there are exceptions such as Farol Island, Rocas Atoll (Costa et al., 2017). However, studies analyzing island response from relatively low SLR rates of the past century ( $0.2 \mathrm{~m}$ of SLR) may not accurately portray how islands will respond in the near future (by 2100$)$ to greater SLR rates $(\sim 0.5-$ $2.0 \mathrm{~m}$ by 2100; Church et al., 2013; Kopp et al., 2014; Slangen et al., 2014) and elevations similar to those at the time of island formation (Dickinson, 2004; Kench et al., 2005).

While these patterns held true in most cases, some atoll configurations were found to be more resistant to intensification with SLR than others. Wide islands (>500 m) with comparably shallow $(<1 \mathrm{~m})$ and wide $(>500 \mathrm{~m})$ reef flats were more resistant to enhanced erosion and accretion magnitudes with SLR (Figure 5). Shallow, wide reef flats provide protection from incident wave attack regardless of island configuration, and wider islands result in comparably less transport potential regardless of atoll morphology. Shoreline stability responds complexly to changing atoll diameter. The most stable (smallest transport gradients/erosion magnitudes) configuration for windward and oblique islands is a wide island $(>500 \mathrm{~m})$ on a small-diameter $(<20 \mathrm{~km})$ atoll, whereas leeward island shorelines tend to be more stable when the atoll diameter is greater than $40 \mathrm{~km}$. A simple implication is that, smaller, narrower (generally uninhabited) islands are likely to see more alongshore transport with SLR than larger, wider (generally inhabited) islands. Yates et al. (2013) observed significant erosional response to SLR at two narrow, uninhabited islands on Manuae Atoll. On the other hand, inhabited islands tend to be wider (resistant to transport gradient changes, Figures 2-4) as there is greater space and more freshwater resources (Bailey et al., 2010). Additionally, as SLR always resulted in a proportionally larger intensification of transport gradients compared to varying morphologies alone. A morphologically stable island with high SLR could experience greater erosion than an unstable island without SLR.

It is important to note that the projection of shoreline change in Figure 5 does not incorporate how the island planform area may change due to increased overwash and inundation with SLR (e.g., Storlazzi et al., 2015). Increased overwash coupled with the limited sediment production in an atoll environment could dramatically alter the island morphology and position on the reef platform, likely narrowing the islands as they build vertically from overland sediment deposition (Smithers and Hoeke, 2014) and migrate toward the lagoon. The assumption of a constant

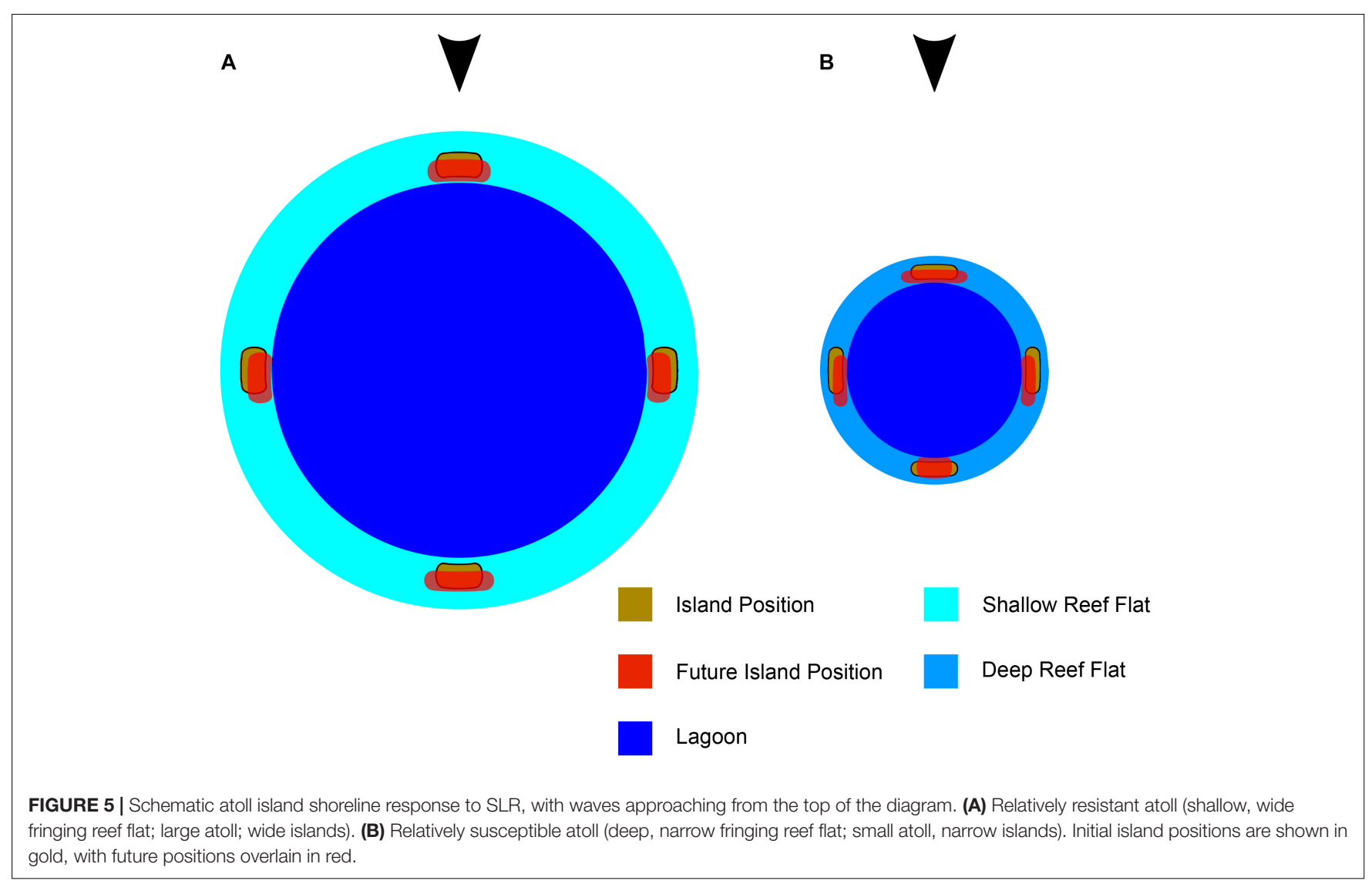


sediment supply also ignores how the islands may change in the future due to new sediment influx and deposition into the lagoon or off the reef platform. Finally, as incident wave energy is the primary driver of the CERC transport formula, larger wave conditions at the model boundary (increased $H_{s}$ or $T_{p}$ ) would increase sediment mobilization and smaller waves would decrease sediment mobilization. This change increase or decrease calculated erosion and accretion magnitudes, respectively.

Comparing these stability scenarios with observational studies is difficult due to the influence of other sediment transport controls, such as wave climate, shoreline composition, or smaller water level variations. Holistic projections of island morphological change should not be considered independently from these other transport controls. One atoll location could have all the morphological hallmarks of greater instability, but its wave climate may be less energetic, its shorelines composed beach rock or armor, or its sediment production smaller when compared to a more "stable" scenario.

\section{CONCLUSION}

The morphology of an atoll and its islands impacts nearshore wave-energy gradients that drive alongshore morphological change. Because atoll islands are generally dynamic features (Kench and Brander, 2006; Rankey, 2011) and these alongshore wave-energy gradients will increase with SLR, future island alongshore transport patterns will change considerably. Schematic, physics-based modeling can help elucidate the control of individual morphological characteristics on potential alongshore transport changes that future SLR may bring. Additionally, one can evaluate an individual atoll island's relative proclivity for enhanced alongshore sediment transport with SLR, regardless of in situ data availability. The strongest modeled morphological controls on alongshore sediment transport are the island width and reef flat depth; reef flat width and atoll diameter play an important but lesser role. Atoll islands that are most susceptible to enhanced transport gradients with SLR (shoreline instability) are narrow $(<500 \mathrm{~m})$, located on small atolls $(<20 \mathrm{~km})$, with narrow $(<500 \mathrm{~m})$, and deep $(>1 \mathrm{~m})$ reef flats. Relative to incident wave direction, windward and oblique islands shorelines are projected to extend toward the lagoon, retreating from the reef rim following SLR-enhanced transport gradients. Leeward islands are expected to become longer and narrower as sediment is redistributed along the island ends. In general, these most susceptible islands are likely to be uninhabited, due to limited water resources and opportunity for infrastructure development. Even so, as SLR is expected to accelerate at unprecedented rates over the next century,

\section{REFERENCES}

Adams, P. N., Inman, D. L., and Lovering, J. L. (2011). Effects of climate change and wave direction on longshore sediment transport patterns in Southern California. Clim. Change 109, 211-228. doi: 10.1007/s10584-011-0317-0 many atoll islands will likely see increased coastal change and threatened coastal infrastructure.

While this methodology is useful for a first-order analysis, future efforts should address many of the aforementioned limitations and improve the accuracy of schematic atoll models. A numerical, coupled hydrodynamic and sediment transport model is necessary to accurately simulate wave-driven alongshore transport around an atoll island and capture the complexities that govern shoreline evolution. A vital addition would be to incorporate cross-shore wave models that can simulate infragravity waves and their associated run-up. A model that incorporates long period waves would be able to accurately simulate overwash and vertical island accretion from successive onshore transport events to build a more complete picture of how islands may respond to changing sea levels and varying morphologies.

\section{AUTHOR CONTRIBUTIONS}

JS constructed and ran schematic atoll models, analyzed model results, and wrote most of the manuscript. CS provided guidance, additional analysis, and edited and contributed to the final manuscript.

\section{FUNDING}

This project was funded by the USGS's Coastal and Marine Geology Program and Department of Defense's Strategic Environmental Research and Development Program (SERDP) under RC-2334. Funding was also provided by the Dr. Earl H. Myers and Ethel M. Myers Oceanographic and Marine Biology Trust and Wells Fargo Coastal Sustainability Fellowship.

\section{ACKNOWLEDGMENTS}

This work was carried out under the USGS's Coral Reef Project as part of an effort in the United States and its trust territories to better understand the effect of geologic and oceanographic processes on coral reef systems and the USGS's Coastal Climate Impacts to the Project to understand the impact of climate change on U.S. and U.S.-affiliated island shorelines. Neil Ganju (USGS) contributed numerous excellent suggestions and a timely review of our work. Thanks to Tony Kimmet of the USDA-NRCSNational Geospatial Center of Excellence for imagery acquisition. Use of trademark names does not imply USGS endorsement of products. Data used in this study can be found and downloaded at: Shope and Storlazzi, 2019, http://doi.org/10.5066/P9U28JFO.

Ashton, A. D., and Murray, A. B. (2006). High-angle wave instability and emergent shoreline shapes: 1. modeling of sand waves, flying spits, and capes. J. Geophys. Res. Earth Surf. 111:F04011. doi: 10.1029/2005JF000422

Bailey, R. T., Jenson, J. W., and Olsen, A. E. (2010). Estimating the ground water resouces of atoll islands. Water 2, 1-27. doi: 10.3390/w2010001 
Beetham, E. P., and Kench, P. S. (2014). Wave energy gradients and shoreline change on vabbinfaru platform. Maldives. Geomorphology 209, 98-110. doi: 10.1016/j.geomorph.2013.11.029

Beetham, E., Kench, P. S., O'Callaghan, J., and Popinet, S. (2016). Wave transformation and shoreline water level on Funafuti Atoll, Tuvalu. J. Geophys. Res. Oceans 121, 311-326. doi: 10.1002/2015JC011246

Booij, N., Ris, R. C., and Holthuijsen, L. H. (1999). A third-generation wave model for coastal regions - 1. model description and validation. J. Geophys. Res. Oceans 104, 7649-7666. doi: 10.1029/98JC02622

Cheriton, O. M., Storlazzi, C. D., and Rosenberger, K. J. (2016). Observations of wave transformation over a fringing coral reef and the importance of low-frequency waves and offshore water levels to runup, overwash, and coastal flooding. J. Geophys. Res. Oceans 121, 3121-3140. doi: 10.1002/2015JC0 11231

Church, J. A., Clark, P. U., Cazenave, A., Gregory, J. M., Jevrejeva, S., Levermann, A., et al. (eds) (2013). "Sea Level Change," in Climate Change 2013: The Physical Science Basis. Contribution of Working Group I to the Fifth Assessment Report of the Intergovernmental Panel on Climate Change, (Cambridge: Cambridge University Press).

Costa, M. B., Macedo, E. C., and Siegle, E. (2017). Planimetric and volumetric changes of reef islands in response to wave conditions. Earth Surf. Process. Landforms. 42, 2663-2678. doi: 10.1002/esp.4215

Dickinson, W. (2004). Impacts of eustasy and hydro-isostasy on the evolution and landforms of Pacific atolls. Palaeogeogr. Palaeoclimatol. Palaeoecol. 213, 251-269. doi: 10.1016/j.palaeo.2004.07.012

Dickinson, W. R. (2009). Pacific atoll living: how long already and until when. GSA Today 19:4. doi: 10.1130/GSATG35A.1

Ferrario, F., Beck, M. W., Storlazzi, C. D., Micheli, F., Shepard, C. C., and Airoldi, L. (2014). The effectiveness of coral reefs for coastal hazard risk reduction and adaptation. Nat. Commun. 5:3794. doi: 10.1038/ncomms4794

Ford, M. (2012). Shoreline changes on an urban atoll in the Central Pacific Ocean: Majuro Atoll, Marshall Islands. J. Coast. Res. 28, 11-22. doi: 10.2112/ JCOASTRES-D-11-00008.1

Ford, M., Becker, J., and Merrifield, M. (2013). Reef flat wave processes and excavation pits: observations and implications for Majuro Atoll, Marshall Islands. J. Coast. Res. 29, 545-554. doi: 10.2112/JCOASTRES-D-12-00097.1

Gourlay, M. R. (1996). Wave set-up on coral reefs. S. set-up on reefs with various profiles. Coast. Eng. 28, 17-55. doi: 10.1016/j.marpolbul.2010.06.023

Grady, A. E., Moore, L. J., Storlazzi, C. D., Elias, E., and Reidenbach, M. A. (2013). The influence of sea level rise and changes in fringing reef morphology on gradients in alongshore sediment transport. Geophys. Res. Lett. 40, 3096-3101. doi: $10.1002 /$ grl.50577

Grigg, R. W. (1982). Darwin point: a threshold for atoll formation. Coral Reefs 1, 29-34. doi: 10.1007/BF00286537

Grothe, P. R., Taylor, L. A., Eakins, B. W., Carignan, K. S., Lim, E., Warnken, R. R., et al. (2010a). Digital Elevation Models of Midway Island: Procedures, Data Sources and Analysis, NOAA Technical Memorandum NESDIS NGDC-33. Boulder, CO: Dept. of Commerce, 24.

Grothe, P. R., Taylor, L. A., Eakins, B. W., Carignan, K. S., Warnken, R. R., Lim, E., et al. (2010b). Digital Elevation Models of Wake Island: Procedures, Data Sources and Analysis, NOAA Technical Memorandum NESDIS NGDC-32. Boulder, CO: Dept. of Commerce, 22.

Harney, J. N., and Fletcher, C. H. I. I. I. (2003). A budget of carbonate framework and sediment production, Kailua Bay, Oahu Hawaii. J. Sed. Res. 73, 865-868. doi: 10.1306/051503730856

Hoeke, R., McInnes, K., and O'Grady, J. (2015). Wind and wave setup contributions to extreme sea levels at a tropical high island: a stochastic cyclone simulation study for Apia. Samoa. J. Mar. Sci. Eng. 3, 1117-1135. doi: 10.3390/ jimse 3031117

Hoeke, R. K. (2010). An Investigation of Wave-Dominated Coral Reef Hydrodynamics. Ph. D thesis, James Cook University, Townsville.

Hoeke, R., Storlazzi, C., and Ridd, P. (2011). Hydrodynamics of a bathymetrically complex fringing coral reef embayment: wave climate, in situ observations, and wave prediction. J. Geophys. Res. 117:C04018. doi: 10.1029/2010JC006170

Hoeke, R. K., McInnes, K. L., Kruger, J. C., McNaught, R. J., Hunter, J. R., and Smithers, S. G. (2013). Widespread inundation of Pacific islands triggered by distant-source wind-waves. Glob. Planet. Change 108, 128-138. doi: 10.1016/j. gloplacha.2013.06.006
Kench, P. S., and Brander, R. W. (2006). Response of reef island shorelines to seasonal climate oscillations: South Maalhosmadulu atoll, Maldives. J. Geophys. Res. 111:F01001. doi: 10.1029/2005JF000323

Kench, P. S., Brander, R. W., Parnell, K. E., and McLean, R. F. (2006). Wave energy gradients across a Maldivian atoll: implications for island geomorphology. Geomorphology 81, 1-17. doi: 10.1016/j.geomorph.2006.03.003

Kench, P. S., McLean, R. F., and Nichol, S. L. (2005). New model of reef-island evolution: Maldives, Indian Ocean. Geology 33, 145-148.

Kench, P. S., Nichol, S. L., Smithers, S. G., McLean, R. F., and Brander, R. W. (2008). Tsunami as agents of geomorphic change in mid-ocean reef islands. Geomorphology 95, 361-383. doi: 10.1016/j.geomorph.2007.06.012

Kench, P. S., Parnell, K. E., and Brander, R. W. (2009). Monsoonally influenced circulation around coral reef islands and seasonal dynamics of reef island shorelines. Mar. Geol. 266, 91-108. doi: 10.1016/j.margeo.2009.07.013

Komar, P. D. (1971). The mechanics of sand transport on beaches. J. Geophys. Res. 76, 713-721. doi: 10.1029/jc076i003p00713

Komar, P. D. (1998). Beach Processes and Sedimentation. Upper Saddle River, NJ: Prentice-Hall.

Kopp, R. E., Horton, R. M., Little, C. M., Mitrovica, J. X., Oppenheimer, M., Rasmussen, D. J., et al. (2014). Probabilistic 21st and 22nd century sea-level projections at a global network of tide-gauge sites. Earth's Future 2, 383-406. doi: 10.1002/2014EF000239

Lowe, R. J., Falter, J. L., Bandet, M. D., Pawlak, G., Atkinson, M. J., Monismith, S. G., et al. (2005). Spectral wave dissipation over a barrier reef. J. Geophys. Res. 110:C04001.

Mandlier, P. G., and Kench, P. S. (2012). Analytical modelling of wave refraction and convergence on coral reef platforms: implications of island formation and stability. Geomorphology 159, 84-92. doi: 10.1016/j.geomorph.2012.03.007

McLean, R., and Kench, P. (2015). Destruction or persistence of coral atoll islands in the face of 20th and 21st century sea-level rise? WIRES Clim. Change 6, 445-463. doi: $10.1002 /$ wcc.350

Montaggioni, L. F. (2005). History of Indo-Pacific coral reef systems since the last glaciation: development patterns and controlling factors. Earth Sci. Rev. 71, 1-75. doi: 10.1016/j.earscirev.2005.01.002

Ohde, S., Greaves, M., Masuzawa, T., Buckley, H. A., Van Woesik, R., Wilson, P. A., et al. (2002). The chronology of funafuti atoll: revisiting an old friend. Proc. $R$. Soc. Math. Phys. Eng. Sci. 458, 2289-2306. doi: 10.1098/rspa.2002.0978

Pelnard-Considere, R. (1956). Essai de Theorie de L'evolution des Formes de Rivage en Plages de Sable et de Galets, in 4th Journees de l'Hydraulique, Les Energies de la Mer, III. Grenoble: La Houille Blanche, 289-298.

Pequignet, A. C., Becker, J. M., Merrifield, M. A., and Boc, S. J. (2011). The dissipation of wind wave energy across a fringing reef at Ipan. Guam. Coral Reefs 30, 71-82. doi: 10.1007/s00338-011-0719-5

Purkis, S. J., Gardiner, R., Johnston, M. W., and Sheppard, C. R. C. (2016). A half-century of coastline change in Diego Garcia - the largest atoll island in the Chagos. Geomorphology 261, 282-298. doi: 10.1016/j.geomorph.2016. 03.010

Quataert, E., Storlazzi, C., van Rooijen, A., Cheriton, O., and van Dongeren, A. (2015). The influence of coral reefs and climate change on wave-driven flooding of tropical coastlines. Geophys. Res. Lett. 42, 6407-6415. doi: 10.1002/ 2015GL064861

Rankey, E. C. (2011). Nature and stability of atoll island shorelines: gilbert Island chain, Kiribati, equatorial Pacific: atoll shoreline change, equatorial Pacific. Sedimentology 58, 1831-1859. doi: 10.1111/j.1365-3091.2011.01241.x

Ris, R. C., Holthuijsen, L. H., and Booij, N. (1999). A third-generation wave model for coastal regions - 2. verification. J. Geophys. Res. Oceans 104, 7667-7681. doi: 10.1029/1998JC900123

Rosati, J. D., Walton, T. L., and Bodge, K. (2002). "Longshore sediment transport," in Coastal Engineering Manual, part II, Coastal Sediment Processes, ed. D. B. King (Washington, D. C: Army, U. S., Corps of Eng.).

Roy, P., and Connell, J. (1991). Climatic-change and the future of atoll States. J. Coast. Res. 7, 1057-1075.

Sheppard, C., Dixon, D. J., Gourlay, M., Sheppard, A., and Payet, R. (2005). Coral mortality increases wave energy reaching shores protected by reef flats: examples from the Seychelles. Estuar. Coast. Shelf Sci. 64, 223-234. doi: 10.1016/ j.ecss.2005.02.016

Shope, J. B., Storlazzi, C. D., Erikson, L. H., and Hegermiller, C. A. (2016). Changes to extreme wave climates of islands within the Western Tropical Pacific 
throughout the 21st century under RCP 4.5 and RCP 8.5 , with implications for island vulnerability and sustainability. Glob. Planet. Change 141, 25-38. doi: 10.1016/j.gloplacha.2016.03.009

Shope, J. B., Storlazzi, C. D., and Hoeke, R. K. (2017). Projected atoll shoreline and run-up changes in response to sea-level rise and varying large wave conditions at wake and Midway Atolls, Northwestern Hawaiian Islands. Geomorphology 295, 537-550. doi: 10.1016/j.geomorph.2017.08.002

Shope, J. B., and Storlazzi, C. D. (2019). Physics-Based Numerical Model Simulations of Wave Propagation Over and Around Theoretical Atoll and Island Morphologies for Sea-Level Rise Scenarios: U.S. Geological Survey Data Release. Available at: http://doi.org/10.5066/P9U28JFO

Slangen, A. B. A., Carson, M., Katsman, C. A., van de Wal, R. S. W., Khol, A., Vermeersen, L., et al. (2014). Projecting twenty-first century regional sea-level changes, Cliatic. Change 124, 317-332. doi: 10.1007/s10584-0141080-9

Smith, E. R., Wang, P., Ebersole, B. A., and Zhang, J. (2009). Dependence of Total longshore sediment transport rates on incident wave parameters and breaker type. J. Coast. Res. 25, 675-683. doi: 10.2112/07-0919.1

Smithers, S. G., and Hoeke, R. K. (2014). Geomorphological impacts of highlatitude storm waves on low-latitude reef islands - observations of the december 2008 event on Nukutoa, Takuu, Papua New Guinea. Geomorphology 222, 106-121. doi: 10.1016/j.geomorph.2014.03.042

Storlazzi, C. D., Elias, E., Field, M. E., and Presto, M. K. (2011). Numerical modeling of the impact of sea-level rise on fringing coral reef hydrodynamics and sediment transport. Coral Reefs 30, 83-96. doi: 10.1007/s00338-0110723-9

Storlazzi, C. D., Elias, E. P. L., and Berkowitz, P. (2015). Many Atolls may be uninhabitable within decades due to climate change. Sci. Rep. 5:14546. doi: $10.1038 /$ srep 14546
Taebi, S., and Pattiaratchi, C. (2014). Hydrodynamic response of a fringing coral reef to a rise in mean sea level. Ocean Dyn. 64, 975-987. doi: 10.1007/s10236014-0734-5

Vousdoukas, M. I., Velegrakis, A. F., and Plomaritis, T. A. (2009). Beachrock occurrence, characteristics, formation mechanisms and impacts. Earth Sci. Rev. 85, 23-46. doi: 10.1016/j.earscirev.2007.07.002

Webb, A. P., and Kench, P. S. (2010). The dynamic response of reef islands to sealevel rise: evidence from multi-decadal analysis of island change in the Central Pacific. Glob. Planet. Change 72, 234-246. doi: 10.1016/j.gloplacha.2010.05.003

Woodroffe, C., McLean, R., Smithers, S., and Lawson, E. (1999). Atoll reef-island formation and response to sea-level change: West Island, Cocos (Keeling) Islands. Mar. Geol. 160, 85-104. doi: 10.1016/S0025-3227(99)00009-2

Woodroffe, C. D. (2008). Reef-island topography and the vulnerability of atolls to sea-level rise. Glob. Planet. Change 62, 77-96. doi: 10.1016/j.gloplacha.2007. 11.001

Yates, M. L., Le Cozannet, G., Garcin, M., Salaï, E., and Walker, P. (2013). Multidecadal Atoll Shoreline change on Manihi and Manuae, French Polynesia. J. Coast. Res. 289, 870-882. doi: 10.2112/JCOASTRES-D-12-00129.1

Conflict of Interest Statement: The authors declare that the research was conducted in the absence of any commercial or financial relationships that could be construed as a potential conflict of interest.

Copyright $\odot 2019$ Shope and Storlazzi. This is an open-access article distributed under the terms of the Creative Commons Attribution License (CC BY). The use, distribution or reproduction in other forums is permitted, provided the original author(s) and the copyright owner(s) are credited and that the original publication in this journal is cited, in accordance with accepted academic practice. No use, distribution or reproduction is permitted which does not comply with these terms. 